\title{
Assessment of Present Heavy Metals in Industrial Affected Soil Area of Mandideep, Madhya Pradesh, India
}

\author{
Narendra Kumar Ahirwar ${ }^{1}$, Govind Gupta ${ }^{2}$, Ravindra Singh ${ }^{1}$ and Vinod Singh ${ }^{2 *}$ \\ ${ }^{1}$ Department of Biological Sciences, MGCGV, Chitrakoot, (M. P.), India \\ ${ }^{2}$ Department of Microbiology, Barkatullah University, Bhopal, (M. P.), India \\ *Corresponding author
}

\begin{tabular}{|c|c|}
\hline & A B S T R A C T \\
\hline $\begin{array}{l}\text { Ke y w o r d s } \\
\text { Industrialization, } \\
\text { Industrial affected } \\
\text { Soil, Heavy } \\
\text { metals, Metal } \\
\text { toxicity, Di - acid } \\
\text { mixture }\end{array}$ & $\begin{array}{l}\text { The Mandideep city is rapid growing city in Madhya Pradesh state, India. In recent days } \\
\text { industrialization is growing in very faster rate than any other activities. Due to } \\
\text { industrialization, the heavy metals pollution load for soil, water and air has increasing day } \\
\text { by day. To find out the heavy metals pollution from the industries which they have } \\
\text { adopted for their production purposes we carried out the research work by dissolving the } \\
\text { extracted soil sample were ground and subsequently digested with } 10 \mathrm{ml} \text { di-acid mixture in } \\
\text { the ratio }(9: 4), 9 \mathrm{ml} \mathrm{HNO}_{3} \text { and } 4 \mathrm{ml} \mathrm{HClO}_{4} \text { was added into the sample and heated on a hot } \\
\text { plate in a fume hood. In the present study it reveals that the heavy metals concentration is }\end{array}$ \\
\hline Article Info & at the nearby maximum level. The results shows that Copper $(\mathrm{Cu})$ level ranges from \\
\hline $\begin{array}{l}\text { Accepted: } \\
\text { 26 June } 2017 \\
\text { Available Online: } \\
10 \text { July } 2017\end{array}$ & $\begin{array}{l}3.8 \mathrm{mg} / \mathrm{kg} \text { to } 15.6 \mathrm{mg} / \mathrm{kg} \text {, Chromium }(\mathrm{Cr}) \text { occur in range of } 6.6 \mathrm{mg} / \mathrm{kg} \text { to } 256.0 \mathrm{mg} / \mathrm{kg} \text {, } \\
\mathrm{Cadmium}(\mathrm{Cd}) \mathrm{found} \text { in range of } 2.3 \mathrm{mg} / \mathrm{kg} \text { to } 13.4 \mathrm{mg} / \mathrm{kg} \text {, Lead }(\mathrm{Pb}) \text { in range of } 3.6 \\
\mathrm{mg} / \mathrm{kg} \text { to } 29.99 \mathrm{mg} / \mathrm{kg} \text {, Iron }(\mathrm{Fe}) \text { varies from } 85 \mathrm{mg} / \mathrm{kg} \text { to } 470 \mathrm{mg} / / \mathrm{kg} \text { whereas Nickel }(\mathrm{Ni}) \\
\text { was found in a range of } 4.8 \mathrm{mg} / \mathrm{kg} \text { to } 26.31 \mathrm{mg} / \mathrm{kg} \text {, and } \mathrm{Zinc}(\mathrm{Zn}) \text { found in range of } \\
44 \mathrm{mg} / \mathrm{kg} \text { to } 139 \mathrm{mg} / \mathrm{kg} \text {. }\end{array}$ \\
\hline
\end{tabular}

\section{Introduction}

Heavy metals are often used as a group name for metals and semimetals (metalloids) that have been associated with contamination and potential toxicity or ecotoxicity.

Heavy metal pollution of the soil is caused by various metals especially copper, Nickel, Cadmium, Zinc, Chromium, and lead (Mass et al., 2010). During the last few decades, the Mandideep, Madhya Pradesh India, has undergone rapid industrial and economic development. It could face public health and ecological problems if heavy metal loads exceed a critical value. Little information is available on heavy metal concentrations on soils of Mandideep.

A large number of industrial activities produce wastes and contaminants that reach the soil through direct disposal, spills, leaks, atmospheric deposition from air, and other pathways. Hence, enhanced metal levels (e.g., $\mathrm{Cu}, \mathrm{Zn}, \mathrm{Pb}, \mathrm{Co}, \mathrm{Ni}, \mathrm{Cd}$, As, and others) in soil media have been reported from in and around several industrial sites. Health risk caused by heavy metals to the inhabitants of a gold mining area, soil samples were collected and analyzed for Asernic (As), Lead (Pb), 
Mercury ( $\mathrm{Hg})$, Cadmium (Cd), Chromium $(\mathrm{Cr})$, Cobalt $(\mathrm{Co})$, Nickel $(\mathrm{Ni})$, Copper $(\mathrm{Cu})$ and Zinc (Zn) using ICP-MS. Measured concentrations of these heavy metals were then used to calculate the health risk for adults and children (Kamunda et al., 2016). As one of the dominant transportation routes of heavy elements, atmospheric emissions have commonly been designated as the main route of metallic accumulation in surface soils via their subsequent deposition, along with other transport routes like waste water discharge. Most of the ground water sources are still supposed to be safe but once, source is contaminated, then practically it would be very difficult to clean that up. Heavy metal toxicity concentration found was $1.22,0.96$ and $922 \mathrm{ppm}$ for $\mathrm{Fe}, \mathrm{Pb}$ and $\mathrm{Na}$ metal respectively in ground water of Khajuwala area in Bikaner division of western Rajasthan (Pandey et al., 2006).

Heavy metal pollution of soil and wastewater is a significant environmental problem (Cheng, 2003). Wastewaters from the industries and sewage sludge applications have permanent toxic effects to human and the environment (Rehman et al., 2008) Cadmium is one of the most toxic pollutants of the surface soil layer, released into the environment by mining and smelting activities, atmospheric deposition from metallurgical industries, incineration of plastics and batteries, land application of sewage sludge, and burning of fossil fuels (Tang et al., 2006). Nickel (Ni) is the 24th most abundant element in the earth crust and has been detected indifferent media in all parts of the biosphere. Activated carbons prepared form rice husk, tamarind nut and peanut hulls have been sucessfully employed for the removal or $\mathrm{Cr}$ (VI), $\mathrm{Hg}$ (II) $\mathrm{Cd}$ (II) and $\mathrm{Ni}$ (II) form aqueous solution. Coconut oilcake residue is and effective adsorbent for the removal and recovery of $\mathrm{Ni}$ (II) from aqueous solution. Its adsorption capacity is moderatly high to commercial activated carbon (Srinivasan and Saravanan, 2006). Hexavalent chromium and trivalent chromium are the most prevalent species of chromium in the natural environment (Chung et al., 2006). Major sources of chromium pollution include effluents from leather tanning, chromium electroplating, wood preservation, alloy preparation and nuclear wastes due to its use as a corrosion inhibitor in nuclear power plants (Thacker et al., 2006).

Unlike organic contaminants, metals are not degradable and thus remain in the environment for long periods of time; when present at high concentrations, metals can negatively affect plant metabolism (Dahbi et $a l .$, 2002). Industrial wastes are major source of heavy metals pollution in India due to inadequate wastewater treatment system. Heavy metals are harmful to humans and animals, tending to accumulate in the food chain. Tanneries and distilleries are important source of chromium $(\mathrm{Cr})$, copper $(\mathrm{Cu})$, manganese $(\mathrm{Mn})$, iron $(\mathrm{Fe})$, nickel $(\mathrm{Ni})$, cadmium $(\mathrm{Cd})$, lead $(\mathrm{Pb})$, and zinc $(\mathrm{Zn})$ pollution in the environment (Babel and Kurniawan 2003, Farabegoli et al., 2004, Chandra et al., 2004a and 2004b). In addition, mining metallurgical activities, smelting of metal ores and fertilizers have contributed to high level of heavy metal concentrations in the environment (Alloway 1998, Ramana et al., 2012 and 2013). Chromium is one of the most toxic heavy metals which deteriorate the environment. Some bacteria producing plant growth activity like production of indole acetic acid, phosphate solublization, siderophores etc are capable of stimulating plant growth and phytoremediation of heavy metal contaminated soil (Gupta et al., 2015).

Enhanced concentrations ( $\mathrm{mg} \mathrm{kg}^{-1}$ ) of $\mathrm{Mn}$ (652), $\mathrm{Pb}(85), \mathrm{Zn}$ (92), and $\mathrm{Cu}$ (47) were also found in soils surrounding the mining and smelting areas in Tharsis, Spain (Chopin and Alloway, 2007). These authors reported the maximum concentrations (mg $\mathrm{kg}-1)$ of 
metals in soil dry matter (DM): Cd (14), $\mathrm{Cr}$ $(3,865), \mathrm{Cu}(1,107)$, Ni (3,579), Pb (172), and Zn (2,495). Borgna et al., (2009) measured 12 trace elements (As, Cd, Co, Cr, $\mathrm{Cu}, \mathrm{Ni}, \mathrm{Pb}$, $\mathrm{Sb}, \mathrm{Th}, \mathrm{Tl}, \mathrm{U}$, and $\mathrm{Zn}$ ) in top soils from the smelter site in the K. Mitrovica area, Kosovo. They reported considerably elevated median values $(\mathrm{mg} \mathrm{kg}-1)$ for $\mathrm{Pb}, \mathrm{Zn}$, and $\mathrm{Cu}$ of 294 , 196, and 37.7, respectively. 2-Hydroxy-3methoxybenzaldehyde modified chelating resin coupled with FAAS offers an excellent method that facilitates the determination of trace analytes and the efficient separation of heavy metals from various matrices found in natural samples (including water resources with high salinity)

The selective removal of toxic metal ions and recovery of precious metal ions in terms of environmental protection and economic consideration are of great significance.

Various type of solid support, such as Amberlite XAD resins, activated carbon, polyurethane foam, Ambersorb, and silica gel, have been used to preconcentrate trace metal ions from various media (Ahmed et al., 2013). All metals except $\mathrm{Ni}$ were detected in 18 soil samples collected near textile industrial facilities with their mean values being $(\mathrm{mg} \mathrm{kg}-1)$ of $(\mathrm{Pb}) 191,(\mathrm{Mn}) 668,(\mathrm{Cu})$ 109, (Cr) 586, (Fe) 380, and (Cd) 83.6 (Deepali and Gangwar, 2010).

The mean concentrations (mg $\mathrm{kg}-1)$ of trace metals were determined to be $\mathrm{Cr}$ (744), $\mathrm{Zn}$ (0.97), $\mathrm{Cu}$ (0.04), Fe (37.7), and As (0.04) in soil samples in the vicinity of leather industries in India (Ahirwar et al., 2015).

$\mathrm{Ni}$ and $\mathrm{Zn}$ in excess of tolerable levels, set as $50 \mathrm{mg} \mathrm{kg}-1$ and $290 \mathrm{mg} \mathrm{kg}-1$, respectively, in the soil samples of ceramic industry sites in Bangladesh. High levels (mg kg-1) of $\mathrm{Pb}$ (268) and Zn (169) were also found near battery manufacturing facilities, which are suspected to pollute the soil in the industrial area of Baoji city, China ( $\mathrm{Li}$ and Huang, 2007).

\section{Materials and Methods}

\section{Soil collection}

In the present study the samples were collected during dry season and wet season of 2014. Soil samples were first collected randomly from industrial contaminated soil areas nearby Pharmaceutical industry, Tractor manufacturing industry, Food industry, and Leather industry of Mandideep, District Raisen of Madhya Pradesh, India.

\section{Pre-treatment and digestion of the collected soil}

Soil samples were collected in sterilized polythene bags and immediately bought to the laboratory. Soil samples were air - dried in a circulating air in the oven at $30^{\circ} \mathrm{C}$ to a constant weight and then passed through a 2 $\mathrm{mm}$ sieve and stored in dry labelled plastic and taken to the laboratory for pretreatment and analyses. Soil samples for heavy metals determination were digested according to the procedure described by Sharidah (1999). The dried soil samples were digested with $10 \mathrm{ml}$ di-acid mixture $\left(9 \mathrm{ml} \mathrm{HNO}_{3}: 4 \mathrm{ml} \mathrm{HClO}_{4}\right)$ and the concentration of $\mathrm{Cr}, \mathrm{Cd}, \mathrm{Cu}, \mathrm{Fe}, \mathrm{Pb}, \mathrm{Zn}$, and $\mathrm{Ni}$, was determined with Atomic Absorption Spectrophotometer (Perkin Elmer). Standard solutions prepared by appropriate dilution of the stock solution 1000 $\mu \mathrm{g} / \mathrm{mL}$ were used to calibrate the device by means of the standard curve method. The detection limit for all analyzed heavy metals was $0.015 \mathrm{mg} . / \mathrm{kg}$. The accuracy of the results obtained in this study was assessed by preparing blank solutions the same manner as employed for the digested soil samples. The blank solutions were checked and found to be uncontaminated. The data was analyzed 
statistically and the treatment means were compared using LSD technique at $5 \%$ probability appropriate for CRBD (Gomez and Gomez, 1984).

\section{Results and Discussion}

\section{Present Heavy metals concentration in soil}

The result of chemical analysis carried out on soils of the industrial environment where heavy metals pollution was observed is shown in Table 1 and 2. Generally, higher concentration of heavy metals was observed in all soils sample was found in dry season followed by wet season. Among all the heavy metals detected in the soil, highest concentration of $\mathrm{Cr}$ was observed in polluted soil $(256 \mathrm{ppm})$ while the lowest concentration of Lead $(\mathrm{Pb})$ was observed in soil (19.99 ppm).

\section{Cadmium}

Cadmium is one of the most toxic pollutants of the surface soil layer, released into the environment by mining and smelting activities, atmospheric deposition from metallurgical industries, incineration of plastics and batteries, land application of sewage sludge, and burning of fossil fuels (Tang et al., 2006).

Average levels of $\mathrm{As}, \mathrm{Cd}, \mathrm{Cr}, \mathrm{Ni}, \mathrm{Hg}$ and $\mathrm{Pb}$ were $0.013,0.017,0.057,0.002,0.094$ and $0.034 \mathrm{mg} / \mathrm{kg}$ (fresh weight), respectively. The samples with $0.25 \%$ for $\mathrm{Cd}$ and $1.56 \%$ for $\mathrm{Pb}$ were exceeding the maximum allowable concentrations (MACs) set by the Chinese Health Ministry (Pan et al., 2016). Cadmium (Cd) in one of the heavy metals which is most mobile and bioavailable and is of high concern for its ecotoxicity. This has been demonstrated in various studies showing impact of $\mathrm{Cd}$ contamination on soil, groundwater, ecosystems and agriculture (Moradi et al., 2005, Keller et al., 2002,
Vander and Griffioen, 2008). In the present study cadmium was found with the concentration of $2.3 \mathrm{mg} / \mathrm{kg}$ to $11.6 \mathrm{mg} / \mathrm{kg}$ in wet season and $3.5 \mathrm{mg} / \mathrm{kg}$ to $13.4 \mathrm{mg} / \mathrm{kg}$ in dry season.

The average value of chromium was found to be $7.11 \mathrm{mg} / \mathrm{kg}$ in wet season and $8.20 \mathrm{mg} / \mathrm{kg}$ in dry season (Figure.1).

\section{Chromium}

Chromium is used on a large scale in many different industries, including metallurgical, electroplating, production of paints and pigments, tanning, wood preservation, $\mathrm{Cr}$ chemicals production, and pulp and paper production.

The leather industry is the major cause for the high influx of $\mathrm{Cr}$ to the biosphere, accounting for $40 \%$ of the total industrial use (Brown et al., 2011). (Chandra et al., 1997), estimated that in India alone about 2600 to 4200 tonnes of elemental $\mathrm{Cr}$ escape into the environment annually from the tanning industries, with a $\mathrm{Cr}$ concentration ranging between 2000 and $5000 \mathrm{mg} \mathrm{L}-1$ in the effluent compared to the recommended permissible limit of $2 \mathrm{mg} \mathrm{L}-1$. Typical concentrations in natural soils are 1$1000 \mathrm{mg} / \mathrm{kg}$ soil (Cappuyns et al., 2002). In the present study chromium was found with the concentration of $6.6 \mathrm{mg} / \mathrm{kg}$ to $246.0 \mathrm{mg} / \mathrm{kg}$ in wet season and $6.9 \mathrm{mg} / \mathrm{kg}$ to $256.0 \mathrm{mg} / \mathrm{kg}$ in dry season. The average value of chromium was found to be $45.52 / \mathrm{kg}$ in wet season and $53.34 / \mathrm{kg}$ in dry season (Figure 2).

\section{Copper}

Copper is naturally present in soils with the range of 0 to $250 \mathrm{mg} / \mathrm{g}$ (Alloway 1994). According to the literature the heavy metal concentration in urban and roadside soils is reported to be 5-10 times higher than the normal concentrations (Baker and Senft 1995). Copper is usually used in all the 
industries as a electrical purposes and it would be change over from time to time and finally it would be discarded as one of the waste material.

The copper content in the industrial affected soils area during wet season ranged from 3.8 $\mathrm{mg} / \mathrm{kg}$ to $9.0 \mathrm{mg} / \mathrm{kg}$ and varied up to 6.2 $\mathrm{mg} / \mathrm{kg}$ to $15.6 \mathrm{mg} / \mathrm{kg}$ for dry season. The average value of copper was found to $6.85 \mathrm{mg}$ $/ \mathrm{kg}$ in wet season and $12.55 \mathrm{mg} / \mathrm{kg}$ in dry season (Figure.3).

\section{Lead}

Lead $(\mathrm{Pb})$ a major pollutant that is found in soil, water and air is a hazardous waste and is highly toxic to human, animals, plants and microbes (Low et al., 2000). Lead (Pb) is one of the ubiquitously distributed most abundant toxic elements in the soil.

Inhibition of germination may result from the interference of lead with important enzymes.

The lead content in the industrial affected soils area during wet season ranged from 3.6 $\mathrm{mg} / \mathrm{kg}$ to $24.6 \mathrm{mg} / \mathrm{kg}$ and varied up to 3.9 $\mathrm{mg} / \mathrm{kg}$ to $29.9 \mathrm{mg} / \mathrm{kg}$ for dry season.

The average value of lead was found to be $9.92 \mathrm{mg} / \mathrm{kg}$ in wet season and $13.10 \mathrm{mg} / \mathrm{kg}$ in dry season (Figure.4).

Table.1 Total heavy metal concentration in industrial affected soil area during wet season- 2014

\begin{tabular}{|l|c|c|c|c|c|c|l|}
\hline & \multicolumn{7}{|c|}{ All results are expressed in mg/kg } \\
\cline { 2 - 8 } Sample No. & $\mathrm{Cd}$ & $\mathrm{Cr}$ & $\mathrm{Cu}$ & $\mathrm{Pb}$ & $\mathrm{Fe}$ & $\mathrm{Zn}$ & $\mathrm{Ni}$ \\
\hline & & & & & & & \\
NKS-1 & 6.5 & 88.3 & 9.0 & 8.9 & 448.0 & 83.1 & 16.2 \\
NKS-2 & 5.7 & 33.7 & 6.7 & 6.9 & 155.6 & 71.6 & 15.0 \\
NKS-3 & 2.3 & 6.6 & 8.2 & 24.6 & 246.3 & 44.0 & 17.9 \\
NKS-4 & 9.1 & 11.4 & 6.8 & 22.3 & 387.4 & 57.5 & 11.2 \\
NKS-5 & 11.7 & 13.5 & 3.8 & 7.6 & 185.5 & 132.5 & 16.6 \\
NKS-6 & 5.9 & 12.9 & 5.3 & 8.4 & 237.5 & 81.4 & 14.8 \\
NKS-7 & 4.4 & 246 & 6.6 & 5.7 & 153.2 & 69.5 & 4.8 \\
NKS-8 & 7.5 & 16.8 & 6.0 & 3.6 & 312.5 & 58.6 & 22.6 \\
NKS-9 & 6.8 & 16.3 & 7.2 & 13.5 & 410.9 & 95.4 & 10.8 \\
NKS-10 & 8.3 & 53.5 & 7.8 & 5.4 & 164.2 & 60.0 & 11.8 \\
NKS-11 & 7.1 & 37.1 & 8.7 & 5.8 & 279.6 & 59.8 & 10.2 \\
NKS-12 & 10.1 & 10.2 & 6.2 & 6.4 & 335.3 & 127.9 & 23.5 \\
\hline
\end{tabular}

Table.2 Total heavy metal concentration in industrial affected soil area during dry season- 2014 


\begin{tabular}{|c|c|l|l|l|l|l|l|}
\hline & \multicolumn{7}{|c|}{ All results are expressed in mg/kg } \\
\cline { 2 - 8 } Sample No. & $\mathrm{Cd}$ & $\mathrm{Cr}$ & $\mathrm{Cu}$ & $\mathrm{Pb}$ & $\mathrm{Fe}$ & $\mathrm{Zn}$ & $\mathrm{Ni}$ \\
\hline & & & & & & & \\
NKS-1 & 7.3 & 105.0 & 12.3 & 17.3 & 470.0 & 89.1 & 20.8 \\
NKS-2 & 6.9 & 39.8 & 9.1 & 9.4 & 167.2 & 77.9 & 19.7 \\
NKS-3 & 3.5 & 6.9 & 12.6 & 29.9 & 255.9 & 51.2 & 23.1 \\
NKS-4 & 11.5 & 17.8 & 12.8 & 26.1 & 401.0 & 64.7 & 14.6 \\
NKS-5 & 13.4 & 19.2 & 6.2 & 12.8 & 197.8 & 139 & 20.4 \\
NKS-6 & 6.7 & 19.0 & 11.9 & 13.3 & 246.5 & 86.6 & 18.2 \\
NKS-7 & 4.9 & 256.0 & 15.3 & 7.5 & 160.3 & 74.8 & 5.5 \\
NKS-8 & 8.2 & 24.6 & 13.7 & 3.9 & 325.4 & 66.5 & 26.3 \\
NKS-9 & 7.8 & 23.7 & 15.1 & 16.4 & 423.7 & 101.3 & 13.6 \\
NKS-10 & 9.7 & 65.0 & 12.7 & 7.2 & 178.6 & 64 & 14.3 \\
NKS-11 & 8.0 & 45.0 & 13.2 & 6.3 & 287.2 & 64.5 & 13.9 \\
NKS-12 & 10.5 & 18.1 & 15.6 & 7.2 & 347.8 & 135.7 & 25.6 \\
\hline
\end{tabular}

Fig.1 Seasonal variation of cadmium in industrial affected soil

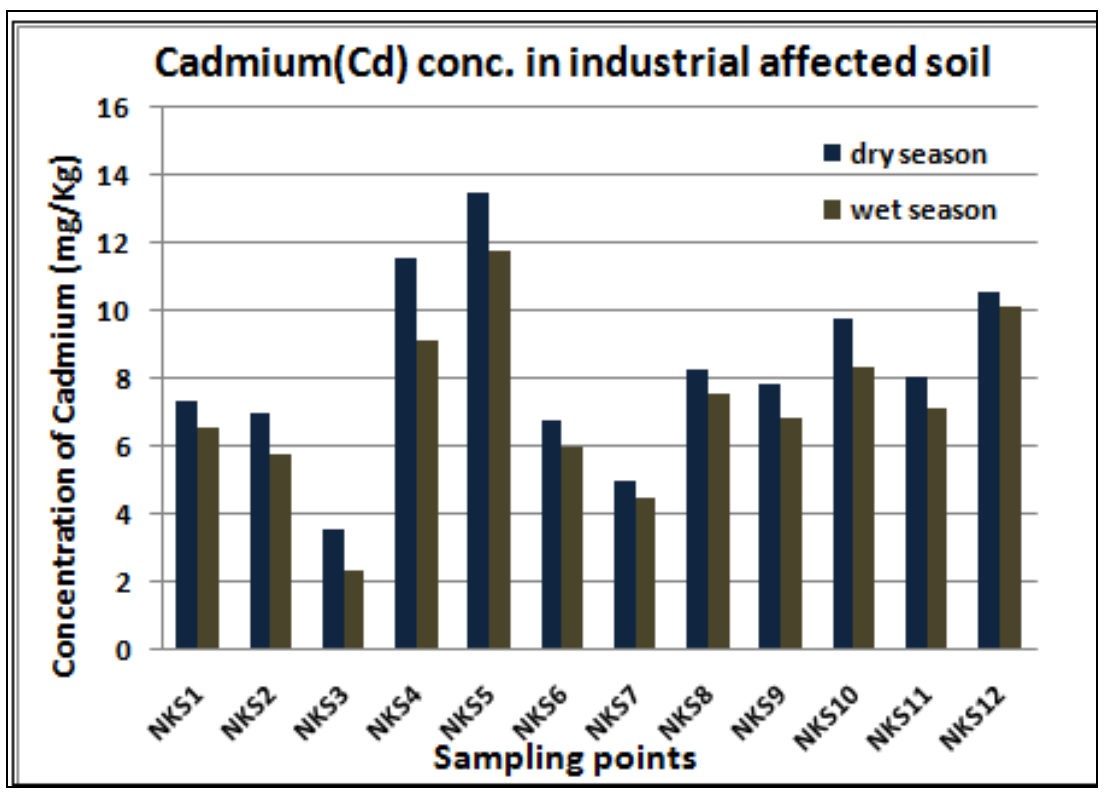


Fig.2 Seasonal variation of chromium in industrial affected soil

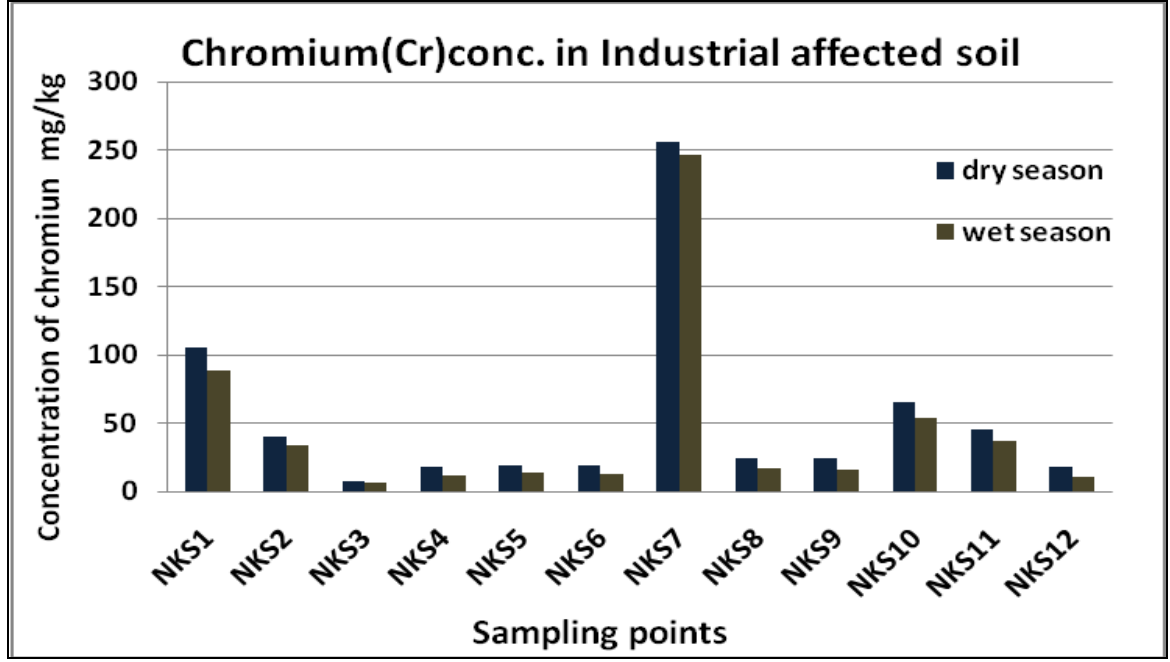

Fig.3 Seasonal variation of copper in industrial affected soil

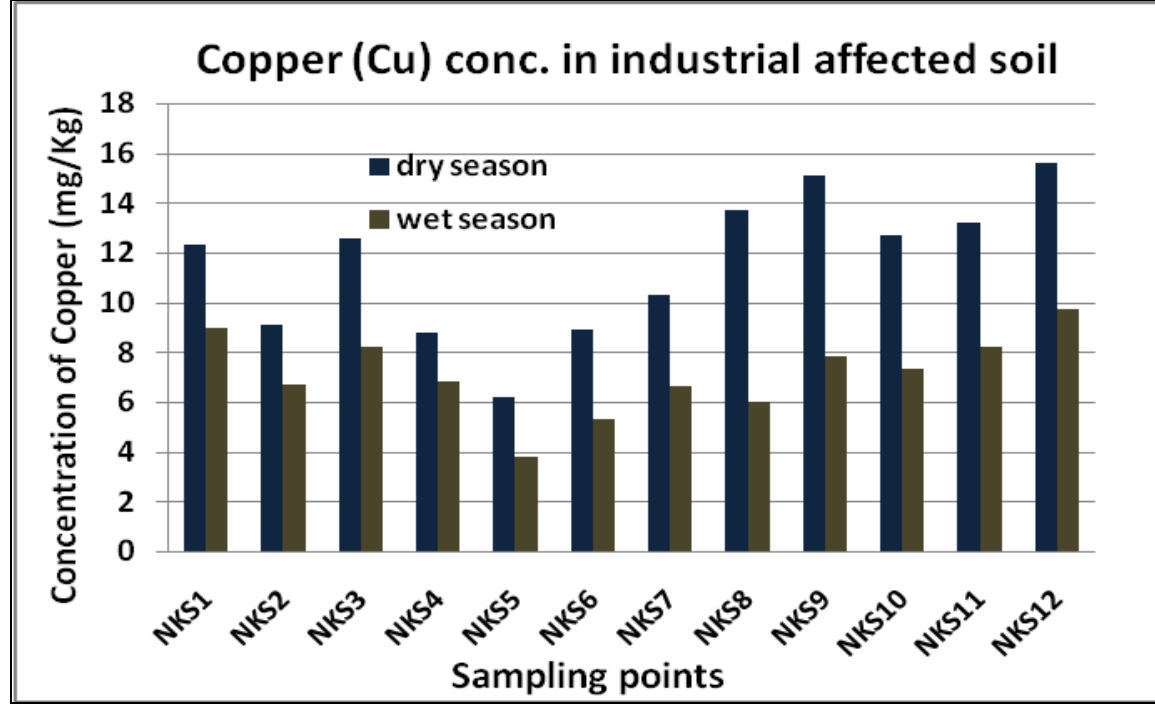

Fig.4 Seasonal variation of lead in industrial affected soil

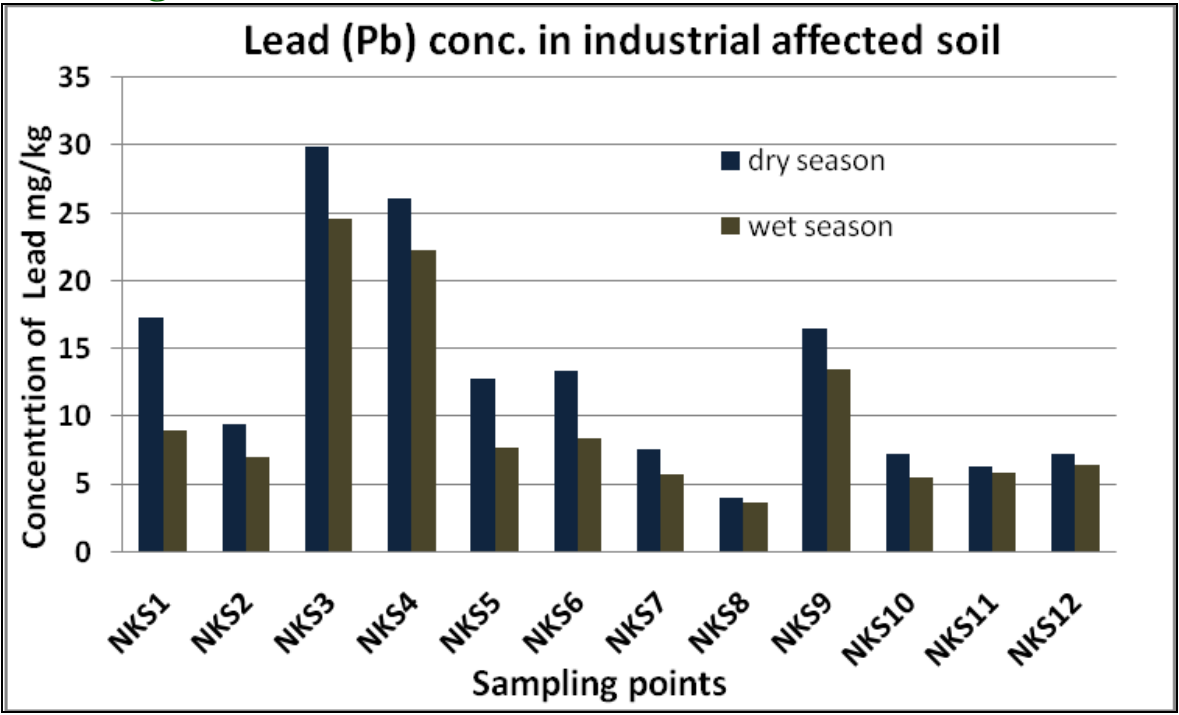


Fig.5 Seasonal variation of iron in industrial affected soil

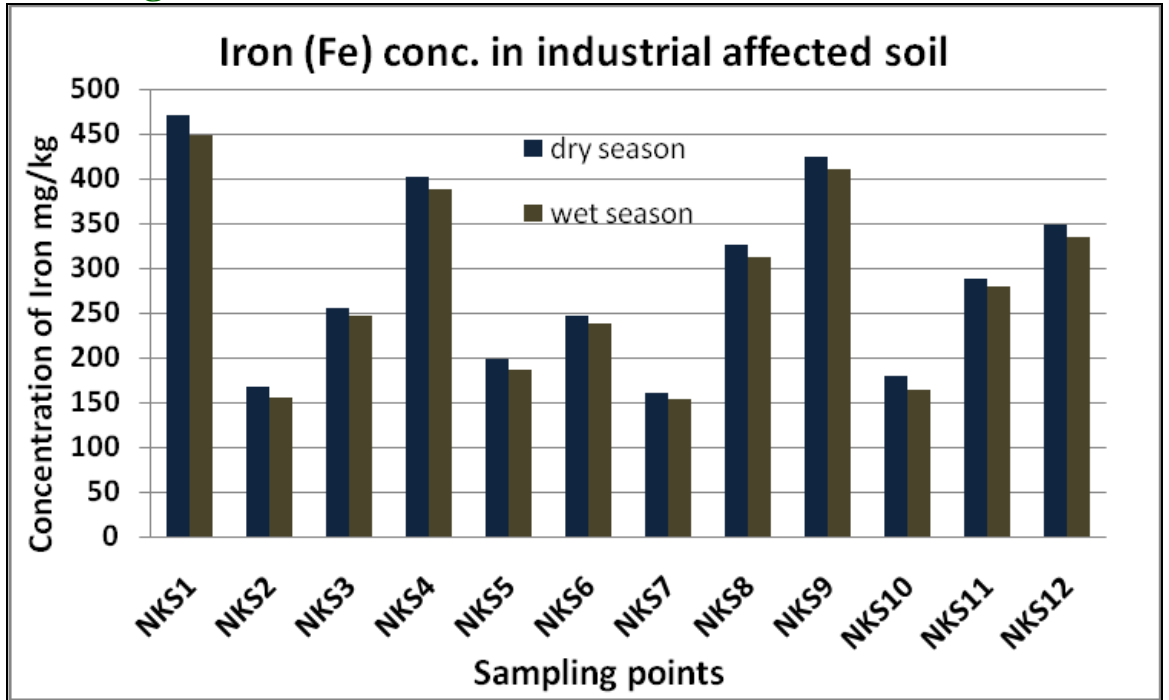

Fig.6 Seasonal variation of zinc in industrial affected soil

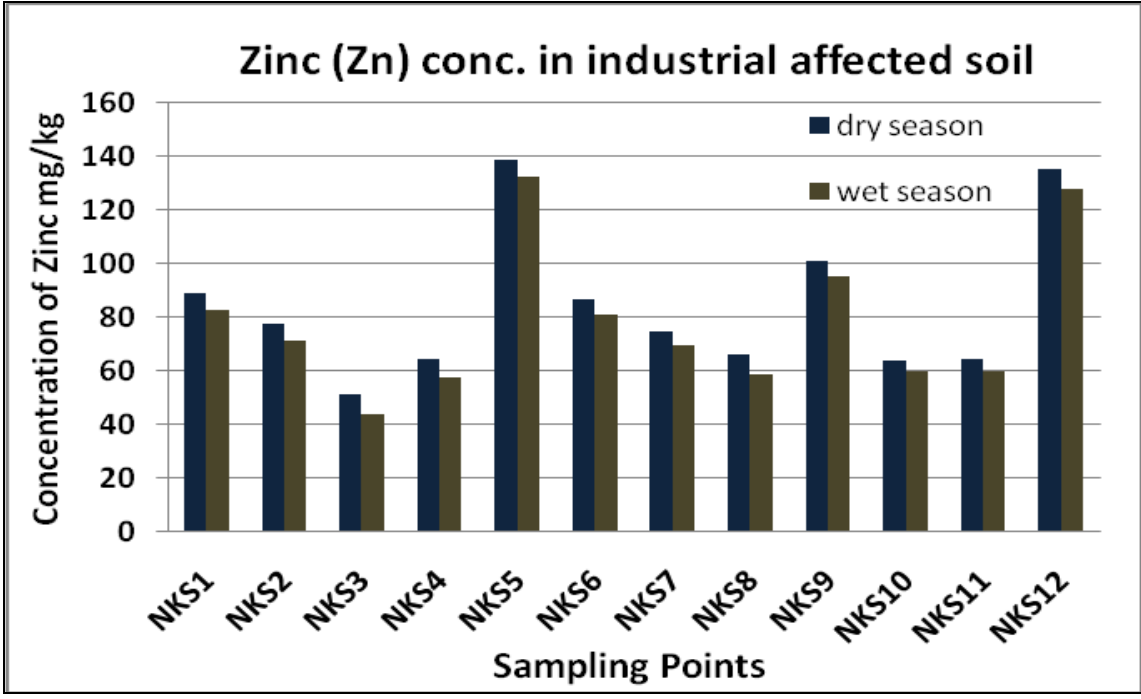

Fig.7 Seasonal variation of nickel in industrial affected soil

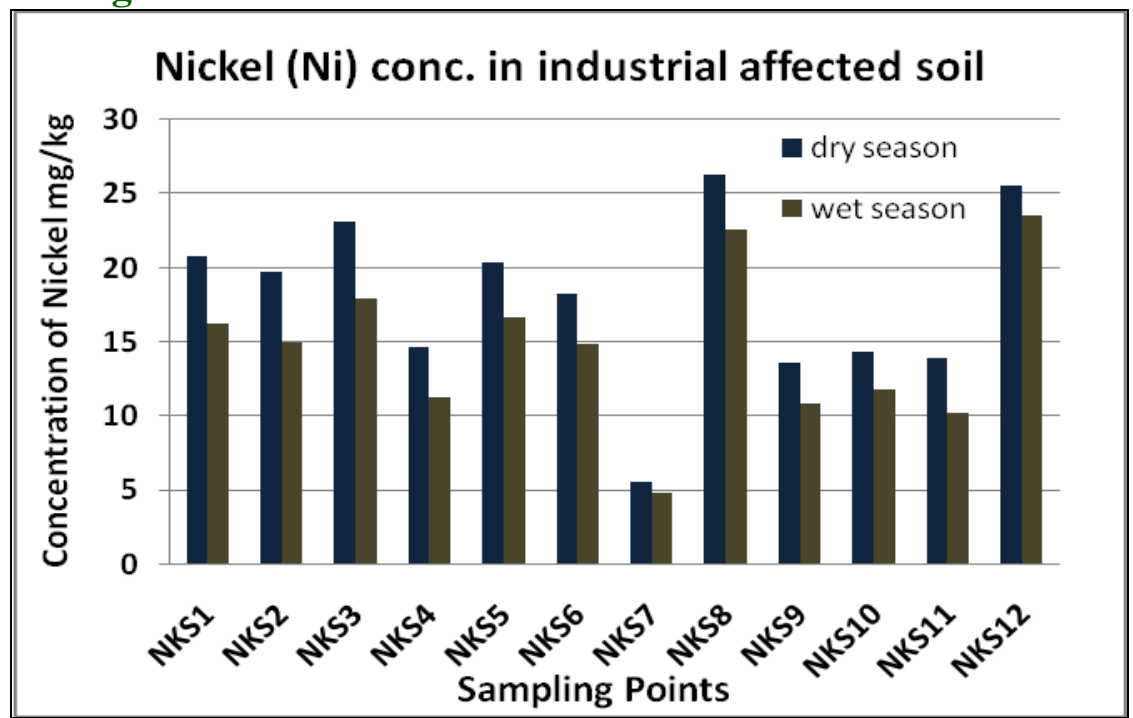




\section{Iron}

The present study reveals that the heavy metal concentration in the study area. Iron is an most essential mineral that is required for human and plants life for their growth. In the industrial fields, iron is major elemental component for all the purposes made by industries. In the present study iron was found with the range of $153.2 \mathrm{mg} / \mathrm{kg}$ to $448 \mathrm{mg} / \mathrm{kg}$ in the wet season with average value of 256.3 $\mathrm{mg} / \mathrm{kg}$ and $160.3 \mathrm{mg} / \mathrm{kg}$ to $470 \mathrm{mg} / \mathrm{kg}$ in wet season with average value of $288.4 \mathrm{mg} / \mathrm{kg}$ (Figure.5).

\section{Zinc}

The normal concentration of zinc in soil is 1 to $900 \mathrm{mg} / \mathrm{g}{ }^{16}$. In the present study, the concentration of zinc little exceeds above the range. This may be due to the higher input of zinc in the roadside environments by heavy motor transport vehicles and from the industrial production and other activities in the study area. In the present study zinc was found with the range from $44.0 \mathrm{mg} / \mathrm{kg}$ to $132.5 \mathrm{mg} / \mathrm{kg}$ for wet season and $51.2 \mathrm{mg} / \mathrm{kg}$ to $139 \mathrm{mg} / \mathrm{kg}$ for dry season respectively. The average value of zinc was found to be 78.44 $\mathrm{mg} / \mathrm{kg}$ in wet season and $84.60 \mathrm{mg} / \mathrm{kg}$ in dry season (Figure.6).

\section{Nickel}

At room temperature the oxidation process of nickels is very slow compare to other metals. So it is considered as corrosion resistant metal. Historically this has led to its use for plating metals such as iron and brass, and it will use in certain alloys that will retain a high silvery polish, such as German silver. About $6 \%$ of world nickel production is still used for corrosion-resistant pure-nickel plating. Nickel was used as a common component of coins, but in later days it has largely replaced by cheaper iron for this purpose. In the present study, nickel was found with the range of 4.8 $\mathrm{mg} / \mathrm{kg}$ to $23.5 \mathrm{mg} / \mathrm{kg}$ for wet season and 5.5 $\mathrm{mg} / \mathrm{kg}$ to $26.3 \mathrm{mg} / \mathrm{kg}$ for dry season respectively. The average value of nickel was found to be $14.61 \mathrm{mg} / \mathrm{kg}$ in wet season and $18.0 \mathrm{mg} / \mathrm{kg}$ in wet season (Figure.7).

This study reported adverse effects of industrial pollution on the soil. It can be concluded that industrial pollution generally increases the heavy metal content of the soil. An assessment of the environmental risk due to soil pollution especially heavy metals is of particular importance for agricultural and non-agricultural areas. Because heavy metals, which are potentially harmful to plants, soil microorganisms and human health, persist in soils for a very long time. When the heavy metals present in the natural condition they do not act as toxic up to certain extent. When the concentration reaches the maximum level or up to the final permissible level heavy metals will be converted in to toxic in nature and it will lead to the dangerous effects on the surrounding system. Heavy metal contamination in the industrial areas of Mandideep city showed that the heavy metal concentration is slightly higher in dry season compared with wet season. The reason behind the low concentration of heavy metals is metal ion will dilute with the water content in the rainy season. From that the ionic movement will be more. Where as in the non rainy season the movement of the metal ion is less and accumulates somewhere else. Finally it may percolate in to the ground water and cause water pollution also, but precautionary measurement should be taken for futures safe and healthy environment.

\section{References}

Maas, S., Scheifler, R., and Benslama, M., 2010. Spatial distribution of heavy metal concentrations in urban, suburban and agricultural soils in a Mediterranean city 
of Algeria. Environmental Pollution. 158(6): $2294-2301$.

Kamunda, C., Mathuthu, M., and Madhuku, M., 2016. Health Risk Assessment of Heavy Metals in Soils from Witwatersrand Gold Mining Basin, South Africa. Int. J. Environ. Res. Public Health. 13(7): 663.

Pandey, H.K., Gakhar, S., and Chawla, G., 2006. Heavy metal toxicity in ground water of Khajuwala area Located in Bikaner division of western Rajasthan. Current World Environment. 1(1): 41-44

Cheng, S., 2003. Heavy metal pollution in China: origin, pattern and control. Environmental Sciences and Pollution Research. 10: 192-198.

Rehman, A., Zahoor, A., Muneer, B., and Hasnain, S., 2008. Chromium tolerance and reduction potential of a Bacillus sp.ev3 isolated from metal contaminated wastewater. Bulletin of Environmental and Contamination Toxicology. 81: 2529.

Tang X.Y., Zhu Y.G., Cui Y.S., Duan, J., and Tang, L., 2006. The effect of ageing on the bioaccessibility and fractionation of cadmium in some typical soils of China. Environment International. 32: 682-689.

Srinivasan, K., and Saravanan, S.S., 2006. Removal of $\mathrm{Ni}(\mathrm{ii})$ form water by agricultural waste: Oil removed coconut residues. Current World Environment. 1(1): 27-34

Chung, J., Nerenberg, R., and Rittmann, B.E., 2006. Bio-reduction of soluble chromate using a hydrogenbased membrane bioflim reactor. Water Research. 40: 1634-1642.

Thacker, U., Parikh, R., Shouche, Y., and Madamwar, D., 2006. Hexavalent chromium reduction by Providencia sp. Process Biochemistry. 41:1332-1337.

Dahbi, S., Azzi, M., Saib, N., De la Guardia, M., Faure, R., and Durand R., 2002. Removal of trivalent chromium from tannery waste waters using bone charcoal. Analytical and Bioanalytical Chemistry. 374(3): 540-546.
Babel, S., and Kurniawan, T. A., 2003. Lowcost adsorbents for heavy metals uptake from contaminated water: a review. Journal of Hazardous Materials. 97 (13): 219-243.

Farabegoli, G., Carucci, A., Majone, M., and Rolle, E., 2004. Biological treatment of tannery wastewater in the presence of chromium. Journal of Environmental Management. 71 (4): 345-349.

Chandra, R., Kumar, K., Singh, J., 2004a. Impact of anaerobically treated and untreated (raw) distillery effluent irrigation on soil microflora, growth, total chlorophyll and protein contents of Phaseolus aureus L. J Environ Biol. 25(4):381-385.

Chandra R, Pandey PK, Srivastava A., 2004b. Comparative toxicological evolution of untreated and treated tannery effluent with Nostoc muscorum L. (Algal assay) and microtox bioassay. Environ Mon Assess. 95:287-294.

Alloway, BJ., (1994). Toxic metals in soil-plant systems. Wiley, UK.

Ramana, S., Biswas AK., Ajay, Singh AB., Ahirwar NK., 2012. Phytoremediation of chromium by tuberose. Natl Acad Sci Lett. 35(2): 71-73.

Ramana, S, Biswas A.K, Ajay, Singh A.B, and Ahirwar N.K., 2013. Phytoremediation ability of some floricultural plant species. Indian J Plant Physiol. 18(2):187-190.

Gupta, G., Parihar, S.S., Ahirwar, N.K., Snehi, S.K., and Singh, V., 2015. Plant Growth Promoting Rhizobacteria (PGPR): Current and Future Prospects for Development of Sustainable Agriculture. J Microb Biochem Technol. 7: 096-102.

Chopin, E. I. B., and Alloway, B. J., 2007. Trace element partitioning and soil particle characterisation around mining and smelting areas at Tharsis, Riotinto and Huelva, SW Spain. Science of the Total Environment. 373 (2-3): 488-500.

Borgna, L., Di Lella, L. A., Nannoni, F., 2009. The high contents of lead in soils of Northern Kosovo. Journal of 
Geochemical Exploration. 101 (2): 137146.

Ahmad, A., Khatoon, A., Laskar, M. A., Islam, A., Mohammad, A.W., and Yong, N. L., 2013. Use of 2-hydroxy-3methoxybenzaldehyde functionalized amberlite xad-16 for preconcentration and determination of trace metal ions by flame atomic absorption spectrometry. Der Pharma Chemica. 5(1):12-23

Deepali, K. K., and Gangwar, K., 2010. Metals concentration in textile and tannery effluents, associated soils and ground water. New York Science Journal. 3(4): 82-89.

Ahirwar, N. K., Gupta, G., and Singh, V., 2015. Biodegradation of Chromium Contaminated Soil by Some Bacterial Species. International Journal of Science and Research. 4:1024-1029.

Li, X., and Huang, C., 2007. Environment impact of heavy metals on urban soil in the vicinity of industrial area of Baoji city, P.R. China. Environmental Geology. 52(8): 1631-1637.

Sharidah M.M.A., 1999. Heavy metals in mangrove sediments of the United Arab Emirates shoreline (Arabian Gulf). Water Air Soil Pollut. 116: 523-534.

Gomez K.A., and Gomez, A., 1984. Statistical Procedures for Agricultural Research, 2nd Ed. New York: John Wiley \& Sons.

Pan, X.D., Ping G.W., and Jiang X.G., 2016. Levels and potential health risk of heavy metals in marketed vegetables in Zhejiang, China. Sci. Rep. 6, 20317.

Moradi, A., Abbaspour, K.C., and Afyuni, M.., 2005. Modelling field-scale cadmium transport below the root zone of a sewage sludge amended soil in an arid region in
Central Iran. Journal of Contaminant Hydrology 79:187-206.

Keller, A., Abbaspour, K.C., and Schulin, R., (2002). Assessment of uncertainty and risk in modeling regional heavy-metal accumulation in agricultural soils. Journal of Environmental Quality 31: 175-187.

Van der Grift, B., and Griffioen, J., 2008. Modelling assessment of regional groundwater contamination due to historic smelter emissions of heavy metals. Journal of Contaminant Hydrology 96: 48-68.

Brown, R. J. C., Goddard, S. L., Blakley, K. C., and Brown, A. S., 2011. Improvements to standard methodologies for the analytical determination of metals in stationary-source emissions samples. Journal of the Air and Waste Management Association. 61(7):764770.

Chandra, P., Sinha, S., and Rai, U. N., 1997. Bioremediation of $\mathrm{Cr}$ from water and soil by vascular aquatic plants, in Phytoremediation of Soil and Water Contaminants, Kruger E. L.,

Cappuyns, V., Herreweghe, Van S., Swennen, R., Ottenburgs, R., and Deckers, J., 2002. Arsenic pollution at the industrial site of Reppel-Bocholt (North Belgium). Science of the Total Environment. 295(1-3): 217-240.

Baker, D.E., and Senft J.P., 1995. Copper. In: Alloway B.L. (Ed.). Heavy Metals in Soils. Chapman Hall, London, 179-202.

Low, K.S., Lee, C.K., and Liew, S.C., 2000. Sorption of cadmium and lead from aqueous solution by spent grain. Process Biochemistry. 36: 59-64.

\section{How to cite this article:}

Narendra Kumar Ahirwar, Govind Gupta, Ravindra Singh and Vinod Singh. 2018. Assessment of Present Heavy Metals in Industrial Affected Soil Area of Mandideep, Madhya Pradesh, India. Int.J.Curr.Microbiol.App.Sci. 7(1): 3572-3582.

doi: https://doi.org/10.20546/ijcmas.2018.701.419 